\title{
AKAP9/BRAF Fusion Protein
}

National Cancer Institute

\section{Source}

National Cancer Institute. AKAP9/BRAF Fusion Protein. NCI Thesaurus. Code C99595.

A fusion protein (1492 aa, 172 kDa) encoded by the AKAP9/BRAF fusion gene. This protein is comprised of part of the A-kinase anchor protein $9 \mathrm{~N}$-terminus fused to the $\mathrm{C}$ terminal half of the serine/threonine-protein kinase B-raf protein. 